\title{
Profitabilitas, Aktivitas Perusahaan, Tipe Industri dan Pengungkapan Sustainability Report
}

\author{
Ni Luh Sari Wagiswari ${ }^{1}$ \\ Fakultas Ekonomi dan Bisnis \\ Universitas Udayana, Indonesia
}

\author{
I Dewa Nyoman Badera ${ }^{2}$ \\ Fakultas Ekonomi dan Bisnis \\ Universitas Udayana, Indonesia
}

\begin{abstract}
Surel : niluhsariw@gmail.com
ABSTRAK

Perusahaan dan entitas bisnis lainya harus mengungkapkan atau melaporkan kegiatan sosial perusahaan yang dimuat dalam sustainability report. Namun, tingkat pelaporan sustainability report di Indonesia masih tergolong rendah. Tujuan penelitian ini adalah untuk mengetahui pengaruh profitabilitas, aktivitas perusahaan, dan tipe industri terhadap pengungkapan sustainability report. Penelitian ini dilakukan pada perusahaan LQ45 di Bursa Efek Indonesia periode tahun 2017-2019 dengan mengakses web resmi ww.idx.co.id. Populasi pada penelitian ini berjumlah 45 perusahaan. Pengambilan sampel menggunakan teknik purposive sampling. Sampel pada penelitian ini sebanyak 16 perusahaan dengan data observasian sebanyak 48. Teknik analisis yang digunakan dalam penelitian ini adalah analisis regresi linear berganda. Berdasarkan hasil penelitian ditemukan bahwa profitabilitas berpegaruh negatif terhadap pengungkapan sustainability report. Aktivitas perusahaan berpengaruh positif terhadap pengungkapan sustainability report. Tipe Industri tidak berpengaruh terhadap pengungkapan sustainability report.
\end{abstract}

Kata Kunci: Profitabilitas; Aktivitas Perusahaan; Tipe Industri; Sustainability Report.

\section{Profitability, Company Activities, Industry Type and Disclosure of Sustainability Report}

\begin{abstract}
Companies and other business entities must disclose or report the company's social activities included in the sustainability report. However, the level of sustainability report reporting in Indonesia is still low. The purpose of this study was to determine the effect of profitability, company activity, and industry type on the disclosure of sustainability report. This research was conducted at the LQ45 company on the Indonesia Stock Exchange for the period 2017-2019 by accessing the official website ww.idx.co.id. The population in this study amounted to 45 companies. Sampling using purposive sampling technique. The sample in this study were 16 companies with 48 observational data. The analysis technique used in this study was multiple linear regression analysis. Based on the research results, it was found that profitability had a negative effect on the disclosure of sustainability reports. Company activities have a positive effect on sustainability report disclosure. Industry type has no effect on sustainability report disclosure.
\end{abstract}

Keywords: Profitability; Company Activities; Industry Type; Sustainability Report.

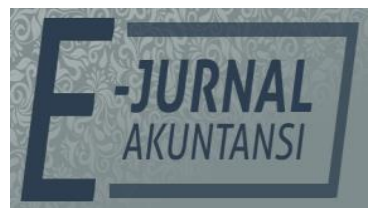

e-ISSN 2302-8556

Vol. 31 No. 9

Denpasar, September 2021 Hal. 2312-2325

DOI:

10.24843/EJA.2021.v31.i09.p13

PENGUTIPAN:

Wagiswari, N.L.S., \& Badera, I.D.N. (2021). Profitabilitas, Aktivitas Perusahaan, Tipe Industri dan Pengungkapan Sustainability Report. E-Jurnal Akuntansi, 31(9), 2312-2325

RIWAYAT ARTIKEL: Artikel Masuk: 1 Januari 2021 Artikel Diterima: 9 September 2021

Artikel dapat diakses : https://ojs.unud.ac.id/index.php/Akuntansi/index 


\section{PENDAHULUAN}

Dewasa ini pembangunan berkelanjutan atau sustainable development merupakan hal penting yang harus diperhatikan oleh perusahaan dan entitas bisnis lainnya dalam melaksanakan bisnisnya. Perusahaan dan entitas bisnis lainya harus mengungkapkan atau melaporkan kegiatan sosial perusahaan yang sesuai dengan nilai - nilai yang terdapat dalam sustainable development agenda. Pengungkapan dan laporan tersebut dimuat dalam sustainability report. Menurut Global Reporting Initiative (GRI), sustainability report merupakan laporan yang diterbitkan oleh perusahaan atau organisasi tentang dampak ekonomi, lingkungan, dan sosial yang disebabkan oleh kegiatan sehari- harinya. Dengan melaporkan laporan berkelanjutan, perusahaan dapat memastikan tata kelola perusahaan serta dampak lingkungan dan sosialnya sesuai dengan harapan dan nilai etika masyarakat sehingga perusahaan dapat berlanjut dalam jangka waktu yang panjang (Finch, 2005).

Dalam pelaporannya, GRI memiliki kerangka pelaporan yang dimuat dalam GRI standards. GRI standards memiliki 3 aspek dan 33 standar topik luas yang terdiri dari aspek ekonomi, sosial dan lingkungan yang dapat diaplikasikan ke seluruh organisasi. Global Reporting Initiative (GRI) dibangun di atas dasar triple bottom line untuk menyediakan kerangka kerja pelaporan dan akuntansi sosial (Finch, 2005). Dalam mewujudkan TBL (Tripple Bottom Line) memerlukan revolusi pemikiran dan tindakan yang terdiri dari tujuh dimensi yaitu markets, values, transparency, life-cycle technology, partnerships, time-perspective dan corporate governance (Elkington, 1997).

Akuntansi dan pelaporan keberlanjutan (SAR) adalah kerangka kerja untuk mendefinisikan variabel keberlanjutan berdasarkan triple bottom line model (TBLM), mendefinisikan dan menerapkan teknik pengukuran, dan melaporkan status aktual dari variabel di publik laporan oleh perusahaan (Bebbington \& Larrinaga, 2014). Sustainability report saat ini terus mengalami perkembangan, karena ekspetasi publik terhadap perusahaan peran di dalam bidang sosial semakin meningkat sementara kepercayaan publik pada bisnis menurun (Dilling, 2010). Sustainability report merupakan cara yang tepat untuk meningkatkan dan mengubah kinerja suatu organisasi ke arah sustainability (Domingues et al., 2017).

Dalam pelaporannya, perusahaan harus melaporkan sustainability report sesuai dengan prinsip - prinsip akuntansi dan standar yang berlaku. Pengungkapan sosial yang dilaporkan oleh perusahaan menginformasikan atau menggambarkan kinerja keberlanjutan sosial perusahaan yang sebenarnya (Papoutsi Sodhi, 2020). Kemunafikan organisasi merupakan masalah yang signifikan saat ini (Higgins et al. 2020). Banyak perusahaan yang memanipulasi laporan perusahaannya untuk menarik perhatian para stakeholders dan mengabaikan prinsip - prinsip yang berlaku. Oleh karena itu, perusahaan harus melaporkan sustainability report secara transparan, tidak hanya sekedar mencari legitimasi dari para stakeholders ataupun masyarakat (Higgins et al., 2020). Perusahaan juga harus menyajikan atau melaporkan sustainability report yang akurat dan kredibel kepada stakeholders tentang kegiatan lingkungan dan sosial mereka terlepas dari dampak ekonomi bagi perusahaan (Comyns et al., 2013). Sustainability report juga menyajikan nilai-nilai organisasi dan model tata kelola, 
dan menunjukkan hubungan antara strategi dan komitmennya terhadap ekonomi global yang berkelanjutan.

Melihat fenomena dan isu - isu saat ini, masih banyak perusahaan yang kurang memperhatikan nilai-nilai sustainable development dan tidak memperhatikan dampak sosial dan lingkungan. Contoh kasus pencemeran lingkungan yang paling marak terjadi yaitu datang dari PT. Rayon Utama Makmur yang berdampak kepada warga sekitar yang bermukim disekitaran PT RUM (Syafina, 2018). Selain itu, kasus pencemeran yang belum lama terjadi selain itu adalah banjir lumpur di Desa Puusuli, Kecamatan Andowia, Kabupaten Konawe Utara (Konut), Sulawesi Tenggara (Sultra). Ratusan rumah warga Desa Puusuli terkena dampak dari banjir lumpur tersebut. Diduga sisa-sisa endapan ore nikel beberapa perusahaan tambanglah yang menyebabkan banjir lumpur tersebut (Harlina, 2020).

Menurut peraturan POJK Nomor 51/POJK.03//2017 di Indonesia yang diterbitkan oleh Otoritas Jasa Keuangan (OJK, 2017), lembaga jasa keuangan, emiten, dan perusahaan publik wajib melaporkan laporan berkelanjutan atau sustainability report. Hanya sebanyak 30\% perusahaan yang melaporkan Sustainability Report (SR) dari sejumlah top 100 perusahaan yang terdaftar du Bursa Efek Indonesia (BEI) (Ernest \& Young, 2016). Sedangkan untuk Global Report Initiative (GRI) hanya sejumlah 97 perusahaan saja yang dihitung dari tahun 200 sampai dengan 2017. Data terbaru dari GRI dan BEI menunjukkan bahwa dari total 629 perusahaan tercatat per 23 April 2019, hanya sebanyak seratus sepuluh laporan keberlanjutan yang sudah dirilis (Kencana, 2019). Tingkat pengungkapan sosial yang rendah dapat terjadi karena perusahaan tidak mengenali potensi strategis pengungkapan sosial dan pada akhirnya melaporkan pelaporannya dengan kualitas yang rendah sesuai hukum yang berlaku (Ullmann, 1985).

Terdapat faktor-faktor yang mempengaruhi pengungkapan sustainability report. Pada penelitian ini peneliti melihat faktor profitabilitas, aktivitas perusahaan dan tipe industri. Profitabilitas adalah suatu yang menunjukan besarnya laba yang diperoleh sebuah perusahaan dari kinerjanya dan akan mempengaruhi catatan laporan keuangan sesuai dengan standar akuntansi yang berlaku. Nilai profitabilitas yang tinggi juga dapat mempengaruhi tingkat nilai pemegang saham (Tobing et al., 2019). Menurut penelitian Tobing et al. (2019) dan Aniswatur Roudtul Jannah \& Kurnia (2016) profitabilitas memiliki pengaruh positif pada pengungkapan sustainability report. Perusahaan yang memiliki profitabilitas tinggi cenderung akan memotivasi perusahaan perusahaan untuk membiayai pengungkapan sustainability report. Adanya pelaporan sustainability report perusahaan adalah untuk lebih dapat dipercaya oleh para stakeholder. Namun hasil tersebut tidak sejalan dengan penelitian Wicaksono \& Septiani (2020), Setiawan et al. (2019), Rifandi (2017), dan Adiatma \& Suryanawa (2018) yang menyatakan bahwa profitabilitas tidak berpengaruh signifikan terhadap pengungkapan sustainability report.

Aktivitas perusahaan digunakan dalam pengukuran kinerja keuangan perusahaan dengan rasio tertentu. Rasio aktivitas mengatur tentang pengelolaan perputaran aktiva, dimana perputarana aktiva sangat penting untuk mengukut kemampuan suatu perusahaan dan melihat efektivitas perusahaan dalam mengelola asetnya (Nasution, 2019). Dalam penelitian Awalia et al. (2015) aktivitas 
perusahaan memiliki pengaruh positif pada pengungkapan sustainability report. Semakin tinggi tingkat rasio aktivitas maka semakin tinggi pengungkapan sustainability report. Namun tidak sejalan dengan penelitian Lestari (2019), Sinaga et al. (2017), dan Aniswatur Roudtul Jannah \& Kurnia (2016) justru menerangkan bahwa aktivitas perusahaan tidak memiliki pengaruh pada pengungkapan sustainability report. Hal ini dikarenakan perusahaan lebih mementingkan aspek keuangan tanpa memperhatikan aspek sosial dan lingkungan (Aniswatur Roudtul Jannah \& Kurnia, 2016).

Ada dua tipe industri dalam sebuah perusahaan, yang pertama adalah tipe high profile dan tipe kedua low profile. Masing-masing dari teipe tersebut memiliki arti yaitu memiliki risiko tinggi dalam politik dan kompetisi dan sebaliknya (Roberts, 1992). Menurut penelitin Sinaga et al. (2017) tipe industri berpengaruh positif terhadap pengungkapan sustainability report. Perusahaan yang memiliki tipe industri high profile cenderung akan mengungkapkan sustainability report untuk menjaga legitimasinya di masyarakat dibandingkan dengan perusahaan yang memiliki tipe industri low profile. Hasil ini tidak sejalan dengan penelitian Syakirli et al. (2019), dan Fitriani (2020) yang menyatakan bahwa tipe industri tidak berpengaruh terhadap pengungkapan sustainability report.

Menurut Freeman (1984) stakeholder merupakan kelompok maupun individu yang dapat mempengaruhi atau dipengaruhi oleh proses pencapaian tujuan suatu organisasi. Teori stakeholder adalah teori yang menggambarkan kepada pihak mana saja perusahaan bertanggungjawab. Terdapat tiga klasifikan dalam menggolongkan stakeholder yaitu .power, legitimacy, dan urgency (Mitchell \& Wood, 1997). Hubungan baik antara perusahaan dan stakeholder-nya harus dijaga dengan baik guna menumbuhkan power dalam ketersediaan sumber daya untuk aktifitas perusahaan seperti tenaga kerja, produk dan sebagainya. (Ghozali et al., 2007). Hubungan yang baik antar perusahaan dan stakeholder dapat mempermudah perusahaan dalam menjalankan aktivitas opersional perusahaan karena stakeholder nantinya akan ikut ambil peran mengambil keputusan yang menentukan bagaimana jalannya perusahaan. Stakeholder secara langsung mempengaruhi ekonomi keberlanjutan, seperti investor, pemegang saham, dan bank, tidak ada perbedaan di setiap sektornya (Kumar et al., 2015).

Menurut Patten (1991) legitimasi suatu perusahaan dapat dilihat atau diukur melalui nilai norma-norma yang berlaku di masyarakat dibandingkan dengan keadaan suatu pasar. Usaha untuk berkegiatan selaras dengan norma-norma yang berlaku dalam masyarakat di lingkungan perusahaan dapat menciptakan situasi untuk mendukung kegiatan operasional perusahaan dari pihak eksternal sehingga terciptanya suatu image yang baik dimata pihak eksternal (Adiatma \& Suryanawa, 2018). Teori legitimasi didasarkan pada gagasan bahwa perusahaan beroperasi dalam masyarakat melalui kontrak sosial, dengan maksud setuju untuk melakukan berbagai tindakan sosial yang diinginkan oleh masyarakat sebagai imbalan atas tercapainya tujuan perusahaan, kelangsungan hidup perusahaan, dan imbalan lainnya (Guthrie \& Parker, 1989). Motivasi perusahaan dalam melaporkan sustainability report didasarkan pada dua prespektif yaitu legitimasi dan akuntanbilitas (Comyns et al., 2013). 
Perusahaan akan selalu memperhatikan legitimasi perusahaannya dan berusaha untuk terus mendapatkan legitimasi di lingkungan sosial. Dalam usaha mendapatkan legitimasi, perusahaan harus mengetahui bagaimana perusahaan dapat mendapatkan, mempertahankan dan kehilangan legitimasi tersebut dan dapat menentukan strategi yang tepat untuk mendapatkan sebuah legitimasi. Menurut O'Donovan (2002) jika perusahaan sudah merasa legitimasinya terancam dan dapat merugikan perusahaannya, maka perusahaan akan mencoba melakukan perubahan dalam persepsi sosial dan mendapatkan legitimasinya kembali.

Profitabilitas adalah ukuran dalam menentukan besaran laba dari kinerja perusahaan yang akan mempengaruhi catatan laporan keuangan sesuai dengan standar yang ada. Perusahaan yang tingkat profitabilitasnya tinggi cenderung menambah biaya sosial dalam laporan berkelanjutannya. Berdasarkan teori stakeholder, perusahaan yang memiliki rasio profitabilitas yang tinggi, maka semakin tinggi pula informasi yang diberikan oleh manajer kepada para pemangku kepentingan. Peruasahaan memiliki kepercayaan diri yang tinggi dan dapat menunjukan kepada para stakeholder bahwa perusahaannya dapat memenuhi harapan mereka, terutama kepada investor dan kreditor (Sinaga et al., 2017). Oleh karena itu, dengan tingkat rasio profitabilitas yang tinggi, perusahaan mampu mengungkapkan sustainability report lebih luas. Menurut penelitian Tobing et al. (2019) dan Aniswatur Roudtul Jannah \& Kurnia (2016) profitabilitas berpengaruh positif terhadap pengungkapan sustainability report.

$\mathrm{H}_{1}$ : Profitabilitas berpengaruh positif dan signifikan terhadap pengungkapan sustainability report.

Aktivitas perusahaan meruapakan rasio penting dalam mengukur kinerja keuangan perusahaan. Rasio aktivitas mengatur tentang pengelolaan perputaran aktiva, dimana perputarana aktiva sangat penting untuk mengukut kemampuan suatu perusahaan dan melihat efektivitas perusahaan dalam mengelola asetnya (Nasution, 2019). Berdasarkan teori stakeholder, semakin tinggi rasio aktivitas menggambarkan bahwa perusahaan sudah efektif dalam mengeola aset nya sehingga perusahaan akan cenderung melakukan pengungkapan yang leih luas untuk mengakomodasi keinginan dan kebutuhan informasi stakeholder-nya terutuma untuk para stakeholder yang memiliki kekuatan atas sumber daya yang akan digunakan dalam aktivitas operasional perusahaan. Dukungan stakeholder dapat dihimpun melalui perusahaan dengan laporan berkelanjutan. Menurut penelitian Awalia et al. (2015) aktivitas perusahaan berpengaruh positif terhadap pengungkapan sustainability report.

$\mathrm{H}_{2}$ : Aktivitas perusahaan berpengaruh positif dan signifikan terhadap pengungkapan sustainability report.

Tipe Industri ada dua, untuk tipe satu adalah high profile dan kedua yaitu low profile dengan ciri yaitu risiko tinggi dalam politik dan perusahaan begitu untuk yang kedua sebaliknya. (Roberts, 1992). Tipe perusahaan yang memiliki high profile memiliki pengaruh yang lebih luas dibandingkan industri yang memiliki low profile. Berdasarkan teori legitimasi, perusahaan yang memiliki high profile cenderung melakukan pengungkapan sustainaility report yang lebih luas. Perusahaan yang memiliki high profile ketika terdapat kesalahan dalam operasionalnya akan mendapatkan soratan yang lebih luas dibandingkan 
perusahaan dengan low profile, oleh karena itu perusahaan cenderung akan terus berusaha mengungkapkan sustainability report agar mendapatkan dan mempertahankan pengakuan dari masyarakat. Perusahan harus menjaga hubungan yang baik dengan stakeholder sehingga perusahaan dapat berjalan berkelanjutan. Perusahaaan dapat mempertanggung jawabkan hal tersebut kepada stakeholder melalui pengungkapan sustainability report. Sehingga nantinya perusahaan mendapatkan kepercayaan dari stakeholder dan mendapatkan legitimasi dari masyarakat. Menurut penelitian Sinaga et al. (2017) tipe industri berpengaruh positif terhadap pengungkapan sustainability report.

$\mathrm{H}_{3}$ : Tipe industri berpengaruh positif dan signifikan terhadap pengungkapan sustainability report.

\section{METODE PENELITIAN}

Penelitian ini menggunakan pendekatan kuantitatif berbentuk asosiatif karena menguji dua variabel atau lebih (Sugiyono, 2017). Penelitian ini dilakukan untuk mengetahui pengaruh profitabilitas, aktivitas perusahaan, dan tipe industri terhadap pengungkapan sustainability report. Penelitian ini dilakukan pada perusahaan LQ45 yang melaporkan laporan berkelanjutan periode tahun 20172019 yang terdaftar dalam Bursa Efek Indonesia (BEI) secara berturut-turut dan diunduh melalui situs resmi masing - masing perusahaan. Obyek dari penelitian ini adalah pengungkapan sustainability report pada perusahaan LQ45 yang melaporkan sustainability report secara berturut-turut pada tahun 2017-2019.

Pengukuran sustainability report pada penelitian ini menggunakan Sustainability Report Disclousure Index (SRDI) yang menilai tanggung jawab sosial dan lingkungan yang sesuai dengan kriteria menurut GRI G4 (Aniswatur Roudtul Jannah \& Kurnia, 2016). Setelah itu total item yang diungkapkan yang meliputi aspek ekonomi, sosial dan lingkungan dijumlahkan dan dibagi dengan total item yang diharapkan 91 .

SRDI $=$ (Jumlah item yang diungkapkan perusahaan $)$

(jumlah item yang diharapkan (91 item))

Pengukuran profitabilitas pada penelitian ini menggunakan Return of Assets (ROA). ROA merupakan salah satu teknik analisis yang digunakan untuk mengukur kinerja keuangan perusahaan dengan melihat seberapa besar pengembalian aset perusahaan dalam menjalankan operasinya. Alasan peneliti memakai ROA yaitu karena rasio ini bersifat menyeluruh dalam artian sistem akuntansi perusahaan sudah berjalan dengan baik jika berdasarkan analisis ROA yang ada dapat mengukur efisiensi penggunaan modal, produksi, dan bagian penjualan (Widianto, 2011). Menurut Aniswatur Roudtul Jannah dan Kurnia (2016) dalam penelitiannya profitabilitas dapat dirumuskan sebagai berikut.

ROA = Laba bersih $\times 100 \%$

Total Aset

Aktivitas perusahaan diukur dengan menggunakan total asset turonover (TATO). Alasan peniliti menggunakan TATO, karena rasio ini digunakan untuk seberapa besar efektifitas perusahaan dalam menggunakan asetnya untuk memperoleh pendapatan atau penjualan yang tinggi. Semakin besar dan efesien perputaran asetnya, maka semakin besar pula pendapatan yang dihasilkan perusahaan tersebut dan menggambarkan kinerja perusahaan yang semakin baik. 
Penjualan yang tinggi menggambarkan kas perusahaan dan laba perusahaan yang baik pula, sehingga nantinya tingkat return yang diharapkan oleh investor akan tinggi juga. Perhitungan dengan rasio ini dinilai lebih memudahkan dalam perhitungan karena asset akun berubah sepanjang tahun, dan banyak investor yang menggunakan dan memperhatikan rasio ini dalam menganalisis harga saham. Menurut Lestari (2019) dalam penelitiannya aktivitas perusahaan dapat dirumuskan sebagai berikut.

TATO $=\frac{\text { Penjualan (sales) }}{\text { Total Aktiva }} \times 100 \%$

Variabel untuk tipe industri diukur dengan variabel dummy, skor 1 diberikan pada perusahaan yang termasuk dalam industry high profile sedangkan skor 0 untuk industry low profile. Pengelompokkan kreteria yang dilakukan ini didasari oleh penelitian (Roberts, 1992). Untuk yang diberikan Nilai 1 adalah industri high profile yaitu, dalam bidang pertambangan, kimia, otomotif, agrobisnis, dan komunikasi, dan kesehatan. Lalu unruk Nilai 0 yaitu produk personal, dan produk rumah tangga yang merupakan perusahaan low profile (Sinaga et al., 2017).

Jenis data dalam penelitian ini data kuantitatif dengan sumber data sekunder yang dalam penelitian ini meliputi sustainability report dan laporan keuangan pada perusahaan LQ45 yang dapat diperoleh melalui website Indonesia Stock Exchange dan website masing - masing perusahaan selama 3 periode (2017 2019). 45 perusahaan menjadi populasi dari penelitian ini dengan metode penentuan sampel yang dilakukan adalah purposive sampling. Dari data observasian yang dilakukan sebanyak 48 data didapat 16 sampel penelitian. Teknik analisis yang digunakan dalam penelitian ini adalah analisis regresi linear berganda, dengan model persamaan regresi.

$Y=\alpha+\beta 1 X_{1}+\beta 2 X_{2}+\beta 3 X_{3}+\varepsilon$

Keterangan:

$\mathrm{Y}=$ Pengungkapan Sustainability Report

$\beta=$ Koefisien Regresi

$X_{1}=$ Profitabilitas

$\mathrm{X}_{2}=$ Aktivitas Perusahaan

$\mathrm{X}_{3}=$ Tipe Industri

$\varepsilon=$ Eror

\section{HASIL DAN PEMBAHASAN}

Tabel 1. Hasil Seleksi Sampel Penelitian

\begin{tabular}{ccc}
\hline No & \multicolumn{1}{c}{ Kriteria Penentuan Sampel } & Jumlah Perusahaan \\
\hline 1 & Perusahaan LQ45 yang terdaftar dalam BEI & 45 \\
2 & $\begin{array}{l}\text { Perusahaan yang tidak melaporkan sustainability report } \\
\text { terpisah dengan annual report secara berkala tahun }\end{array}$ & $(23)$ \\
& $2017-2019$ & 22 \\
Total sampel yang memenuhi kriteria & 3 \\
Tahun pengamatan & 66 \\
Total sampel selama periode sebelum di-outlier & $(18)$ \\
Data sampel outlier & 48 \\
Total sampel penelitian tahun 2017-2019 &
\end{tabular}

Sumber: Data Penelitian, 2020 
Penelitian ini menggunakan perusahaan LQ45 yang melaporkan sustainability report pada periode tahun 2017-2019 secara berkala dan diunduh melalui situs resmi masing - masing perusahaan. Sampel dalam penelitian ini diperoleh melalui teknik purposive sampling, yaitu penentuan sampel dengan kriteria-kriteria tertentu.

Berdasarkan kriteria yang ditentukan, dari 45 perusahaan LQ45 yang terdaftar di Bursa Efek Indonesia periode 2017-2019 diperoleh sampel sebanyak 22 perusahaan dan 23 perusahaan lainnya tidak melaporkan sustainability report terpisah dengan annual report secara berkala 2017-2019. Pada penelitian ini terdapat 18 sampel outlier. Sehingga total sampel tahun 2017-2019 sebanyak 48.

Tabel 2. Hasil Statistik Deskriptif

\begin{tabular}{lccccc}
\hline \multicolumn{1}{c}{ Variabel } & $\mathrm{N}$ & Minimum & Maximum & Mean & $\begin{array}{c}\text { Std. } \\
\text { Deviation }\end{array}$ \\
\hline Pengungkapan SR & 54 & 0,050 & 0,430 & 0,213 & 0,107 \\
Profitabilitas & 54 & $-1,00$ & 14,470 & 4,185 & 3,578 \\
Aktivitas Perusahaan & 54 & 1,170 & 121,460 & 39,198 & 33,606 \\
Tipe Industri & 54 & 0,000 & 1,000 & 0,562 & 0,501 \\
\hline
\end{tabular}

Sumber: Data Penelitian, 2020

Berdasarkan hasil uji statistik deskriptif pada Tabel 2, dijelaskan Nilai standar deviasi seluruh variabel memiliki nilai di bawah rata-rata yang dapat diartikan bahwa data yang digunakan dalam variabel pengungkapan sustainability report memilki sebaran kecil dan sudah merata.

Tabel 3. Hasil Uji Normalitas

\begin{tabular}{llr}
\hline & & Unstandardized Residual \\
\hline $\mathrm{N}$ & & 48 \\
Normal Parameters & Mean & 0,0000000 \\
& Std. Deviation & 0,09679834 \\
Most Extreme Differences & Absolute & 0,071 \\
& Positive & 0,071 \\
& Negative & $-0,060$ \\
Test Statistic & & 0,071 \\
Asymp. Sig. (2-tailed) & & 0,200 \\
\hline
\end{tabular}

Sumber: Data Penelitian, 2020

Berdasarkan Tabel 3, diketahui bahwa Sig. (2-tailed) sebesar 0,200 lebih besar dari level of significant (tingkat signifikansi) 0,05 . Hasil pengujian ini menunjukkan bahwa data yang dianalisis berdistribusi normal.

Tabel 4. Hasil Uji Multikolinearitas

\begin{tabular}{lll}
\hline \multicolumn{1}{c}{ Variabel } & Tolerance & VIF \\
\hline Profitabilitas $\left(\mathrm{X}_{1}\right)$ & 0,436 & 2,295 \\
Aktivitas Perusahaan $\left(\mathrm{X}_{2}\right)$ & 0,240 & 4,167 \\
Tipe Industri $\left(\mathrm{X}_{3}\right)$ & 0,429 & 2,334 \\
\hline
\end{tabular}

Sumber: Data Penelitian, 2020

Berdasarkan hasil uji multikolinearitas pada Tabel 4, variabel profitabilitas, aktivitas perusahaan, dan tipe industri menunjukan nilai tolerance lebih dari 0,1 atau nilai VIF kurang dari 10. Dari keterangan tersebut menyatakan bahwa penelitian tidak terjadi multikolonearitas atau antar variabel bebasnya tidak ada korelasi. 
Tabel 5. Hasil Uji Heteroskedastisitas

\begin{tabular}{lcc}
\hline \multicolumn{1}{c}{ Variabel } & Sig & Keterangan \\
\hline Profitabilitas $\left(\mathrm{X}_{1}\right)$ & 0,325 & Bebas heteroskedastisitas. \\
Aktivitas Perusahaan $\left(\mathrm{X}_{2}\right)$ & 0,602 & Bebas heteroskedastisitas. \\
Tipe Industri $\left(\mathrm{X}_{3}\right)$ & 0,507 & Bebas heteroskedastisitas. \\
\hline
\end{tabular}

Sumber: Data Penelitian, 2020

Berdasarkan hasil uji heteroskedastisitas pada Tabel 5, diketahui nilai signifikansi variabel profitabilitas $\left(X_{1}\right)$, aktivitas perusahaan $\left(X_{2}\right)$, dan tipe industri $\left(\mathrm{X}_{3}\right)$ terhadap variabel pengungkapan sustainability report berada di atas 0,05. Dengan demikian bahwa data dalam penelitian terbebas dari gejalan heterokaedastisitas.

Tabel 6. Hasil Uji Autokorelasi

\begin{tabular}{cccccc}
\hline Model & $\mathrm{R}$ & $\mathrm{R}$ Square & $\begin{array}{c}\text { Adjusted } \mathrm{R} \\
\text { Square }\end{array}$ & $\begin{array}{c}\text { Std. Error of } \\
\text { the Estimate }\end{array}$ & $\begin{array}{c}\text { Durbin- } \\
\text { Watson }\end{array}$ \\
\hline 1 & 0,424 & 0,180 & 0,124 & 0,100 & 1,954 \\
\hline
\end{tabular}

Sumber: Data Penelitian, 2020

Hasil pengujian autokorelasi menerangkan bahwa jumlah nilai DW adalah sebesar 1,954. Dengan demikian dapat dicatat bahwa jumlah sampel $n=48$ dan $k=3$, diperoleh nilai $\mathrm{dL}=1,406$ dan $\mathrm{dU}=1,670$, hal ini juga menghasilkan nilai $4-\mathrm{dL}=$ 2,593 dan nilai $4-\mathrm{dU}=2,329$ maka dapat dirumuskan kriteria $\mathrm{dU}<\mathrm{DW}<4$-dU yaitu $(1,670<1,954<2,329)$. Hal ini menunjukan bahwa tidak terdapat gejala atau masalah autokorelasi.

Tabel 7. Hasil Analisis Regresi Berganda

\begin{tabular}{llrrrrr}
\hline \multirow{2}{*}{ Model } & \multicolumn{2}{c}{$\begin{array}{c}\text { Unstandardised } \\
\text { Coefficients }\end{array}$} & $\begin{array}{c}\text { Standardized } \\
\text { Coefficient }\end{array}$ & \multirow{2}{*}{$\mathrm{t}$} & \multirow{2}{*}{ Sig. } \\
\cline { 3 - 5 } & & \multicolumn{1}{c}{ B } & Std. Error & \multicolumn{1}{c}{ Beta } & & \\
\hline 1 & (Constant) & 0,236 & 0,025 & & 9,359 & 0,000 \\
& X $_{1}$ & $-0,019$ & 0,006 & $-0,629$ & $-3,043$ & 0,004 \\
& $X_{2}$ & 0,002 & 0,001 & 0,564 & 2,024 & 0,049 \\
& $X_{3}$ & $-0,027$ & 0,044 & $-0,125$ & $-0,600$ & 0,552 \\
& Adjusted $R^{2}$ & & & & & 0,124 \\
& Sig.F & & & & & 0,032 \\
\hline
\end{tabular}

Sumber: Data Penelitian, 2020

Berdasarkan Tabel 7, maka persamaan regresi yang digunakan dalam penelitian ini dapat ditulis sebagai berikut.

$$
\mathrm{Y}=0,236-0,019 \mathrm{X}_{1}+0,002 \mathrm{X}_{2}-0,027 \mathrm{X}_{3}+\varepsilon
$$

Tabel 7, memberikan informasi bahwa nilai Adjusted $\mathrm{R}^{2}$ menunjukkan nilai 0,124 artinya sebesar 12,4 persen variasi variabel dependen mampu dijelaskan variase variabel independen dan sisanya dijelaskan variabel lain sebesar 87,6 persen. Nilai signifikansi F yaitu 0,000 menunjukkan nilai lebih kecil dari a $(0,05)$ maka menunjukan secara simultan seluruh variabel dependen berpengaruh terhadap pengungkapan sustainability report artinya model regresi linier berganda layak digunakan.

Hipotesis pertama $\left(\mathrm{H}_{1}\right)$ menyatakan profitabilitas berpengaruh negatif dan signifikan terhadap pengungkapan sustainability report. Hasil koefisien -0,019 dengan tingkat signifikansi 0,004 dari Tabel 7, menunjukkan nilai koefisiensi sebesar -0,019 dengan tingkat signifikan sebesar 0,004 yang lebih rendah dari tingkat taraf nyata. Hal ini menjelaskan bahwa profitabilitas perusahaan LQ45 
yang terdaftar di Bursa Efek Indonesia periode 2017-2019 berpengaruh terhadap pengungkapan sustainability report, namun memiliki pengaruh negatif. Dari analisis dan perhitungan tersebut bahwa hipotesis pertama ditolak.

Hasil penelitian ini bertentangan dengan teori stakeholder yang menyatakan bahwa semakin tinggi rasio profitabilitas suatu perusahaan, maka semakin tinggi pula informasi yang diberikan oleh manajer kepada para pemangku kepentingan, oleh karena itu semakin tinggi pula pengungkapan sustainabilty report. Hasil yang didapat mendukung adanya teori legitimasi yang menjelaskan perusahaan cenderung untuk melakukan pengungkapan sustainability report yang lebih luas untuk menutupi rendahnya profitabilitas yang dimiliki. Perusahaan akan mengalihkan perhatian stakeholder kepada sustainability report sehingga nantinya diharapkan para stakeholder tetap mau menanamkan modalnya di perusahaan tersebut. Hasil penelitian ini sejalan dengan penelitian Sinaga et al. (2017) dan Fauziah (2018) yang menyatakan bahwa profitabilitas berpengaruh negatif terhadap pengungkapan sustainability report.

Hipotesis kedua $\left(\mathrm{H}_{2}\right)$ menyatakan aktivitas berpengaruh positif dan signifikan terhadap pengungkapan sustainability report. Hasil analisis pada Tabel 7, menyatakan nilai koefisiensi sebesar 0,002 dengan tingkat signifikan sebesar 0,049 yang lebih rendah dari tingkat taraf nyata penelitian sebesar 0,05. Hal ini menunjukkan bahwa aktivitas perusahaan perusahaan LQ45 yang terdaftar di Bursa Efek Indonesia periode 2017-2019 berpengaruh positif terhadap pengungkapan sustainability report. Dengan demikian hipotesis kedua pada penelitian ini diterima.

Hasil penelitian ini mendukung teori stakeholder yang menyatakan bahwa semakin tinggi rasio aktivitas menggambarkan bahwa perusahaan sudah efektif dalam mengeola asetnya sehingga perusahaan akan cenderung melakukan pengungkapan yang lebih luas untuk mengakomodasi keinginan dan kebutuhan informasi stakeholdernya terutuma untuk para stakeholder yang memiliki kekuatan atas sumber daya yang akan digunakan dalam aktivitas operasional perusahaan. Hasil penelitian ini sejalan dengan hasil penelitian Awalia et al. (2015) yang menyatakan bahwa aktivitas perusahaan berpengaruh positif terhadap pengungkapan sustainability report.

Hipotesis pertama $\left(\mathrm{H}_{3}\right)$ menyatakan tipe industri berpengaruh positif dan tidak signifikan terhadap pengungkapan sustainability report. Hasil analisis pada Tabel 7, menyatakan nilai koefisiensi sebesar -0,027 dengan tingkat signifikan sebesar 0,552 yang lebih tinggi dari tingkat taraf nyata penelitian sebesar 0,05. Hal ini menunjukkan bahwa tipe industri perusahaan LQ45 yang terdaftar di Bursa Efek Indonesia periode 2017-2019 tidak berpengaruh terhadap pengungkapan sustainability report. Dengan demikian hipotesis ketiga pada penelitian ini ditolak.

Hasil penelitian ini bertentangan teori legitimasi yang menyatakan bahwa perusahaan yang memiliki high profile cenderung melakukan pengungkapan sustainaility report yang lebih luas. Perusahaan yang memiliki high profile ketika terdapat kesalahan dalam operasionalnya akan mendapatkan soratan yang lebih luas dibandingkan perusahaan dengan low profile, oleh karena itu perusahaan cenderung akan terus berusaha mengungkapkan sustainability report agar mendapatkan dan mempertahankan pengakuan dari masyarakat. Tipe industri tidak berpengaruh terhadap pengungkapan sustainability report karena 
pengungkapan sustainability report memang wajib dilakukan oleh semua tipe perusahaan. Menurut penelitian Fitriani (2020) perusahaan dengan high profile maupun low profile memiliki tingkat penngungkapan yang berbeda-beda, sehingga tinggi rendahnya pengungkapan sustainability report tidak bisa ditentukan oleh tipe industri. Seluruh tipe perusahaan akan berusaha dan berlomba - lomba mengungkapkan sustainability report secara lengkap agar mendapatkan legitimasi masyarakat maupun stakeholder. Hasil penelitian ini sejalan dengan penelitian Syakirli et al. (2019) dan Fitriani (2020) yang menyatakan bahwa tipe industri tidak berpengaruh terhadap pengungkapan sustainability report.

\section{SIMPULAN}

Berdasarkan hasil analisis data dan pembahasan yang telah diuraikan pada bab sebelumnya, dapat diambil kesimpulan bahwa profitabilitas berpegaruh negatif dan signifikan terhadap pengungkapan sustainability report pada perusahaan LQ45 periode tahun 2017-2019. Terdapat sebuah penarikan kesimpulan yang menyatakan bahwa ketika perusahaan mengalami profitabilitas rendah maka mereka cenderung akan melakukan pebgungkapan sustainability report secara besar-besaran atau luas.. Aktivitas perusahaan berpengaruh positif dan signifikan terhadap pengungkapan sustainability report pada perusahaan LQ45 periode tahun 2017-2019. Semakin tinggi rasio aktivitas menggambarkan bahwa perusahaan sudah efektif dalam mengeola asetnya sehingga perusahaan akan cenderung melakukan pengungkapan yang lebih luas untuk mengakomodasi keinginan dan kebutuhan informasi stakeholder-nya terutuma untuk para stakeholder yang memiliki kekuatan atas sumber daya yang akan digunakan dalam aktivitas operasional perusahaan. Tipe Industri berpengaruh positif dan tidak signifikan terhadap pengungkapan sustainability report pada perusahaan LQ45 periode tahun 2017-2019. Tipe industri tidak berpengaruh terhadap pengungkapan sustainability report karena pengungkapan sustainability report memang wajib dilakukan oleh semua tipe perusahaan. Perusahaan akan berlomba - lomba mengungkapkan sustainability report secara luas agar mendapatkan legitimasi dari para stakeholder.

Dilihat dari hasil uji statistik, nilai adjusted $\mathrm{R}^{2}$ hanya sebesar 0,124 berarti bahwa variasi variabel independen mampu menjelaskan 12,4 persen variasi variabel dependen, sedangkan sisanya yaitu sebesar 87,6 persen dijelaskan oleh variabel lain. Oleh karena itu, bagi peneliti selanjutnya diharapkan melihat faktor - faktor lain yang sekiranya dapat mempengaruhi pengungkapan sustainability report dengan menambahkan variabel independen lain. Diharapkan pula sebelum melakukan penelitian, cek terlebih dahulu laporan keuangan dan laporan tahunan perusahaan yang akan diteliti sudah lengkap menyajikan variabel yang akan diteliti.

\section{REFERENSI}

Adiatma, K. B., \& Suryanawa, I. K. (2018). Pengaruh Tipe Industri, Kepemilikan Saham Pemerintah, Profitabilitas Terhadap Sustainability Report. E-Jurnal Akuntansi, 25.2, 934-958.

Aniswatur Roudtul Jannah, U., \& Kurnia. (2016). Pengaruh Kinerja Keuangan Terhadap Pengungkapan Sustainability Report Pada Perusahaan Di Bei. 
Jurnal Ilmu Dan Riset Akuntansi, 5(2), 1-15.

Awalia, E. N., Anggraini, R., \& Prihatni, R. (2015). Pengaruh Dewan Direksi, Dewan Komisaris Independen, Laverage, Dan Aktivitas Perusahaan Terhadap Pengungkapan Sustainability report. Jurnal Ilmiah Wahana Akuntansi, 10(2), 124-139.

Bebbington, J., \& Larrinaga, C. (2014). Accounting and sustainable development: An exploration. Accounting, Organizations and Society, 39(6), 395-413. https://doi.org/10.1016/j.aos.2014.01.003

Chariri, A., \& Ghozali, I. (2007). Teori Akuntansi. Badan Penerbit Universitas Diponegoro,.

Comyns, B., Figge, F., Hahn, T., \& Barkemeyer, R. (2013). Sustainability reporting: The role of "Search", "Experience" and "Credence" information. Accounting Forum, 37(3), 231-243. https:/ / doi.org/10.1016/j.accfor.2013.04.006

Dilling, P. F. A. (2010). Sustainability Reporting In A Global Context: What Are The Characteristics Of Corporations That Provide High Quality Sustainability Reports An Empirical Analysis. International Business \& Economics Research Journal (IBER), 9(1), 19-30. https:/ / doi.org/10.19030/iber.v9i1.505

Domingues, A. R., Lozano, R., Ceulemans, K., \& Ramos, T. B. (2017). Sustainability reporting in public sector organisations: Exploring the relation between the reporting process and organisational change management for sustainability. Journal of Environmental Management, 192, 292-301. https://doi.org/10.1016/j.jenvman.2017.01.074

Elkington, J. (1997). John Elkington, Cannibals With Forks: The Triple Bottom Line of 21st Century Business. Journal of Business Ethics, 23(2), 229-231. https://doi.org/10.1023/ A:1006129603978

Ernest \& Young. (2016). Value of sustainability reporting - A study by EY and Boston College. 1-32.

Fauziah, A. (2018). Pengaruh Profitabilitas, Leverage, Likuiditas, Aktivitas Perusahaan, Dan Corporate Governance Terhadap Pengungkapan Sustainability Reporting. In Skripsi Fakultas Ekonomi dan Bisnis Universitas Muhamadiyah Surakarta.

Finch, N. (2005). The Motivations for Adopting Sustainability Disclosure. SSRN Electronic Journal, August. https:// doi.org/10.2139/ssrn.798724

Fitriani, M. (2020). Pengaruh Pertumbuhan Perusahaan, Tipe Industri, Dan Leverage Terhadap Sustainability Reporting Dengan Gcg Sebagai Variabel Moderating (Studi Empiris Pada Perusahaan-perusahaan se-Asia yang Mengikuti ASRA Tahun 2017-2018). In SELL Journal (Vol. 5, Issue 1). Universitas Negeri Semarang.

Freeman, R. E. E., \& McVea, J. (1984). A Stakeholder Approach to Strategic Management. SSRN Electronic Journal, January. https:// doi.org/10.2139/ssrn.263511

Guthrie, J., \& Parker, L. D. (1989). Corporate Social Reporting: A Rebuttal of Legitimacy Theory. Accounting and Business Research, 19(76), 343-352. https://doi.org/10.1080/00014788.1989.9728863

Harlina, S. (2020). Banjir Lumpur di Konawe Utara, Warga Soroti Aktivitas Pertambangan. New.Detik.Com.

Higgins, C., Tang, S., \& Stubbs, W. (2020). On managing hypocrisy: The 
transparency of sustainability reports. Journal of Business Research, 114(October 2018), 395-407. https:// doi.org/10.1016/j.jbusres.2019.08.041

Kencana, M. R. B. (2019). BEI Dorong Perusahaan Tercatat Terapkan Pembangunan Berkelanjutan. Liputan6.Com.

Kumar, V., Gunasekaran, A., Singh, K., Papadopoulos, T., \& Dubey, R. (2015). Cross sector comparison of sustainability reports of Indian companies: A stakeholder perspective. Sustainable Production and Consumption, 4(August), 62-71. https:// doi.org/10.1016/j.spc.2015.08.005

Lestari, N. A. (2019). Pengaruh Aktivitas Perusahaan, Coorperate Governance, dan Indonesia Sustainability Awards (ISRA) Terhadap Pengungkapan Sustainability Report Perusahaan yang Masuk Dalam Indeks Saham Syariah. Universitas Islam Negeri Sunan Kalijaga.

Mitchell, R. K., \& Wood, D. J. (1997). Toward a Theory of Stakeholder Identification and Salience : Defining the Principle of Who and What Really Counts Author ( $s$ ): Ronald K. Mitchell, Bradley R. Agle and Donna J. Wood Source: The Academy of Management Review, Vol. 22 , No . 4 ( Oct . 22(4), 853-886.

Nasution, R. (2019). Sebagai Dasar Penilaian Kinerja Keuangan Pada Skripsi Oleh: Resiyanti Nasution Fakultas Ekonomi Dan Bisnis Universitas Medan Area Medan.

O'Donovan, G. (2002). Environmental disclosures in the annual report: Extending the applicability and predictive power of legitimacy theory. Accounting, Auditing $\mathcal{E}$ Accountability Journal, 15(3), 344-371. https://doi.org/10.1108/09513570210435870

OJK. (2017). Peraturan Otoritas Jasa Keuangan Nomor 51/POJK.03/2017 tentang Penerapan Keuangan Berkelanjutan bagi Lembaga Jasa Keuangan, Emiten, dan Perusahaan Publik. Ojk.Go.Id.

Papoutsi, A., \& Sodhi, M. M. S. (2020). Does disclosure in sustainability reports indicate actual sustainability performance? Journal of Cleaner Production, 260, 121049. https:/ / doi.org/10.1016/j.jclepro.2020.121049

Patten, D. M. (1991). Exposure, legitimacy, and social disclosure. Journal of Accounting and Public Policy, 10(4), 297-308. https://doi.org/10.1016/02784254(91)90003-3

Rifandi, A. (2017). Pengaruh Ukuran Perusahaan, Profitabilitas Dan Leverage Terhadap Sustainability Disclosure. Jurnal Akuntansi Fakultas Ekonomi Dan Bisnis Universitas Negeri Padang, 6(4), 472-480.

Roberts, R. W. (1992). Determinants of corporate social responsibility disclosure: An application of stakeholder theory. Accounting, Organizations and Society, 17(6), 595-612. https:// doi.org/10.1016/0361-3682(92)90015-K

Setiawan, K., Mukhzarudfa, \& Hizazi, A. (2019). Pengaruh Profitabilitas, Solvabilitas, dan Ukuran Perusahaan terhadap Pengungkapan Sustainabiltiy Report pada Perusahaan Perbankan yang Terdaftar di Bursa Efek Indonesia dan Bursa Efek Malaysia Periode 2013-2017. Jurnal Akuntansi Dan Keuangan Unja, 4(2), 30-40.

Sinaga, K. J., Akuntansi, J., Ekonomi, F., \& Semarang, U. N. (2017). The Effect of Profitability, Activity Analysis, Industrial Type and Good Corporate Governance Mechanism on The Disclosure of Sustainability Report. Accounting Analysis Journal, 6(3), 347-358. https://doi.org/10.15294/aaj.v6i3.18690 
Sugiyono. (2017). Metode Penelitian Kuantitatif, Kualitatif, dan RED. Alfabeta, CV. Syafina, D. C. (2018). Relasi PT RUM \& Sritex: Menyembunyikan Bau dari Hidung Sendiri. Tirto.Id.

Syakirli, I., Cheisviyanny, C., \& Halmawati. (2019). Pengaruh Karateristik Perusahaan Terhadap Pengungkapan Sustainability Reporting. Jurnal Eksplorasi Akuntansi, 1(1), 277-289.

Tobing, R. A., Zuhrotun, Z., \& Rusherlistyani, R. (2019). Pengaruh Kinerja Keuangan, Ukuran Perusahaan, dan Good Corporate Governance Terhadap Pengungkapan Sustainability Report pada Perusahaan Manufaktur yang Terdaftar dalam Bursa Efek Indonesia. Reviu Akuntansi Dan Bisnis Indonesia, 3(1), 102-123. https://doi.org/10.18196/rab.030139

Ullmann, A. A. (1985). Data in Search of a Theory: A Critical Examination of the Relationships among Social Performance, Social Disclosure, and Economic Performance of U. S. Firms. The Academy of Management Review, 10(3), 540. https://doi.org/10.2307/258135

Wicaksono, R. R., \& Septiani, A. (2020). Determinan Sustainability Report Dan Pengaruh Terhadap Nilai Perusahaan. Diponegoro Journal of Accounting, 9(2), $1-15$.

Widianto, H. S. (2011). Pengaruh Profitabilitas, Likuiditas, Leverage, Aktivitas, Ukuran Perusahaan, Dan Corporate Governance Terhadap Praktik Pengungkapan Sustainability Report (Studi Pada Perusahaan - Perusahaan yang Listed (Go-Public) di Bursa Efek Indonesia (BEI). Jurnal Akuntansi, 1-83. 